\title{
ADVANTAGE OF NON-CLOSURE OF THE PERITONEUM AT CAESAREAN SECTION
}

\author{
Narayan Bhaumik ${ }^{1}$
}

${ }^{1}$ Associate Professor, Department of Obstetrics \& Gynaecology, Tripura Medical College.

\section{ABSTRACT}

\section{OBJECTIVE}

To determine advantage of non-closure of peritoneum at LSCS over of closure of peritoneum with regard to postoperative complications.

\section{STUDY DESIGN}

Prospective randomized controlled trial.

\section{SETTING}

Tripura Medical College and Dr. BRAM Teaching Hospital, Hapania, Tripura.

\section{SUBJECTS AND METHODS}

Three hundreds term pregnant women undergoing first cesarean section were divided into 2 groups $(\mathrm{N}=150)$. Group I: Non-closure of both visceral and parietal peritoneum. Group II: closure of both visceral and parietal peritoneum. Postoperative complications were compared. Adhesions were evaluated in 50 patients in each group returning for a second LSCS and compared for severity of adhesions.

\section{RESULT}

There was statistical difference between group I and II for postoperative complications or number of adhesion formation. However, adhesions in the closure group were more severe.

\section{CONCLUSIONS}

Non closure of visceral and parietal peritoneum has benefit over closure of both visceral and parietal peritoneum at LSCS. So closure of visceral and parietal peritoneum may be avoided in LSCS.

\section{KEYWORDS}

Non-Closure Peritoneum, Adhesion, Cesarean Delivery.

HOW TO CITE THIS ARTICLE: Bhaumik N. Advantage of non-closure of the peritoneum at caesarean section. J Evolution Med Dent Sci 2016;5(1):79-81, DOI: 10.14260/jemds/2016/18

\section{INTRODUCTION}

Worldwide caesarean section is a very common surgical procedure. Peritoneal closure is a controversial issue among obstetricians and gynaecologists. The peritoneum is a thin membrane of cells supported by a thin layer of connective tissue, and during caesarean section these peritoneal surfaces have to be cut through. Following a caesarean section, it has been standard practice to closure of the peritoneum..$^{1-6}$ as it was thought to possibly allow for (i) restoration of anatomy and approximation of tissues for healing; (ii) re-establishment of the peritoneal barrier to reduce the risk of infection; (iii) reduction of the risk of wound herniation or dehiscence; and (iv) minimizing adhesion formation. ${ }^{1}$ The arguments against non-closure of peritoneum involve the following. 1) Peritoneum has the innate ability to rapidly heal itself.

Financial or Other, Competing Interest: None.

Submission 14-12-2015, Peer Review 15-12-2015,

Acceptance 29-12-2015, Published 04-01-2016.

Corresponding Author:

Dr. Narayan Bhaumik,

Associate Professor,

Department of Obstetrics \& Gynaecology,

Tripura Medical College,

Hapania,

Agartala-14.

E-mail: nbhaumikdr@gmail.com

DOI:10.14260/jemds/2016/18
Being a mesothelial organ with the capacity to initiate multiple sites of repair, the peritoneum can simultaneously heal throughout the wound. In case of non-closure peritoneum a spontaneous reperitonealization. 2,3,7 will appear within 48 to 72 hours and complete healing after 5-6 days. 2) Non-closure of the peritoneum contributes to less adhesion.8,9,10-12 When injured, the peritoneum responds initially by producing a fibrin matrix and proceeds with fibrinolysis to break down the fibrin. Reapproximation of the peritoneal edges with suture material is suspected to result in tissue ischemia, necrosis, foreign body tissue reaction, suppression of fibrinolysis and thus increased risk in adhesion formation. 3) Non-closure of the peritoneum reduces the amount of surgical intervention and saves on valuable operating time and cost.1,2,3,6,13,14,15,16 The objective of this study was to assess the effects of nonclosure and closure of the peritoneum at caesarean section.

\section{MATERIALS AND METHODS}

Three hundred pregnant women were included in this study from January 2007 to January 2014. The peritoneum was left open in 150 cases and in 150 it was closed; 50 (Fifty) women in the nonclosure group and 50 (Fifty) women in the closure group were undergone repeat cesarean section. Detailed history, examinations and investigations, informed written consent was taken for each patient. They were evaluated intraoperatively subsequently. 
Women with preoperative diseases or infections, previous complications of pregnancy or previous laparotomy were excluded. A standard technique for LSCS was performed. The uterine incision was closed with 2 layers of continuous 1 Vicryl suture, the peritoneum with a continuous 00 chromic cat gut, and the fascia with a continuous 1 Vicryl suture. The skin was sutured with subcutaneous continuous by 00 Nylon sutures.

A urinary catheter was routinely inserted throughout the operation and was removed after 24 hours of operation. Prophylactic antibiotics parental form in first two days and oral for next three days were used. The women were controlled for age, parity, indications for LSCS and operation time, infection/febrile episodes, bowel function, post-surgery analgesic/anaesthetic requirement, stay and Pain was evaluated twice a day from the first to the fifth postoperative day by Visual Analog Scales. The presence of adhesions and their severity, hernia were evaluated and recorded. Febrile morbidity was defined as a nonspecific fever above 38 degree Celsius on two occasions at least twelve hours apart.13 Tenderness of the uterus and offensive lochia with fever was diagnosed as Endomyometritis. Wound infection was diagnosed by erythema, induration, or purulent discharge from the skin. Cystitis was diagnosed by clinical dysurination or frequent micturition with more than 1 lack colonies of single sepsis of bacteria per $\mathrm{mL}$ of urine.

During the second LSCS, operative findings concerning intra-abdominal adhesion, including the degree of adhesion were noted. The women were classified into four groups; group with no adhesion, mild adhesion $(<3 \mathrm{~cm}$ band), moderate adhesion $(>3-5 \mathrm{~cm}$ band), and severe adhesion $(>5 \mathrm{~cm}$ band and or difficult to lysis).

\section{RESULTS}

In all 300 cases were analysed and profiles of the patients are shown in the Table No-1. The age of patients ranged from 1836 years and range of parity was $0-3$. All patients were given spinal anaesthesia.

\begin{tabular}{|c|c|c|}
\hline & $\begin{array}{c}\text { Non-Closure } \\
\text { Group }\end{array}$ & $\begin{array}{c}\text { Closure } \\
\text { Group }\end{array}$ \\
\hline Maternal Age (Yrs.) & $18-35$ & $18-36$ \\
\hline Parity & $0-2$ & $1-3$ \\
\hline Anaesthesia (Spinal) & 150 & 150 \\
\hline \multicolumn{2}{|c|}{ Table 1: Patient's Profile } \\
\hline
\end{tabular}

Table No-2 Presents the indications of LSCS. Maximum of patients $(43-46 \%)$ in this study underwent t LSCS due to Foetal distress then formal presentations, CPD and BOH.

\begin{tabular}{|c|c|c|}
\hline & $\begin{array}{c}\text { Non-Closure } \\
\text { Group }\end{array}$ & $\begin{array}{c}\text { Closure } \\
\text { Group }\end{array}$ \\
\hline Foetal distress & 70 & 65 \\
\hline Malpresentation & 30 & 35 \\
\hline CPD & 20 & 22 \\
\hline BOH & 18 & 20 \\
\hline APH & 12 & 08 \\
\hline \multicolumn{2}{|c|}{ Table 2: Indications of Operations } \\
\hline
\end{tabular}

Post-operative complications at First LSCS are illustrated in Table No-3 Mean operation time, i.e. incision to closure of skin, mean anaesthesia time, hospital stay, therapeutic antibiotic requirements, Febrile morbidity of nonclosure group were less than that of closure group.

\begin{tabular}{|c|c|c|}
\hline & $\begin{array}{l}\text { Non-Closure } \\
\text { Group }\end{array}$ & $\begin{array}{l}\text { Closure } \\
\text { Group }\end{array}$ \\
\hline Mean Operation Time & $32 \mathrm{~min}$ & $36 \min$ \\
\hline Mean Anesthesia Time & $40 \mathrm{~min}$ & $45 \mathrm{~min}$ \\
\hline $\begin{array}{l}\text { Post-operative } \\
\text { Hospitalization } \\
\end{array}$ & 6days & 7days \\
\hline $\begin{array}{l}\text { Additional Narcotics } \\
\text { Used }\end{array}$ & $6(4 \%)$ & $12(8 \%)$ \\
\hline Febrile Morbidity & $4(2.66 \%)$ & $10(6.66 \%)$ \\
\hline Wound Infection & $3(2 \%)$ & $3(2 \%)$ \\
\hline Endomyometritis & $2(1.33 \%)$ & $2(1.33 \%)$ \\
\hline Cystitis & $4(2.66 \%)$ & $5(3.33 \%)$ \\
\hline Bowel Function & 18 hrs. & 20 hrs. \\
\hline $\mathrm{Pph}$ & nil & $1(0.66 \%)$ \\
\hline Others Infection & nil & Nil \\
\hline $\begin{array}{l}\text { Antibiotic for } 2 \text { more } \\
\text { days }\end{array}$ & $4(2.66 \%)$ & $10(6.66 \%)$ \\
\hline \multicolumn{3}{|c|}{$\begin{array}{c}\text { Table 3: Postoperative complications } \\
\text { at first LSCS operations }\end{array}$} \\
\hline
\end{tabular}

Table No-4 contains the intra-abdominal adhesions during $2^{\text {nd }}$ LSCS of fifty cases in each group. In this study more adhesions (44\% V/s 20\%) were observed in closure group.

\begin{tabular}{|c|c|c|}
\hline Adhesion & $\begin{array}{c}\text { Non-Closure } \\
\text { Group }\end{array}$ & $\begin{array}{c}\text { Closure } \\
\text { Group }\end{array}$ \\
\hline No adhesion & $40(80 \%)$ & $28(56 \%)$ \\
\hline Mild adhesion & $7(14 \%)$ & $15(30 \%)$ \\
\hline $\begin{array}{c}\text { Moderate } \\
\text { adhesion }\end{array}$ & $3(6 \%)$ & $5(10 \%)$ \\
\hline Severe adhesion & nil & $2(4 \%)$ \\
\hline Total adhesion & $10(20 \%)$ & $22(44 \%)$ \\
\hline \multicolumn{2}{|c|}{ Table 4: Intra-abdominal adhesions found in 2nd LSCS } \\
\hline
\end{tabular}

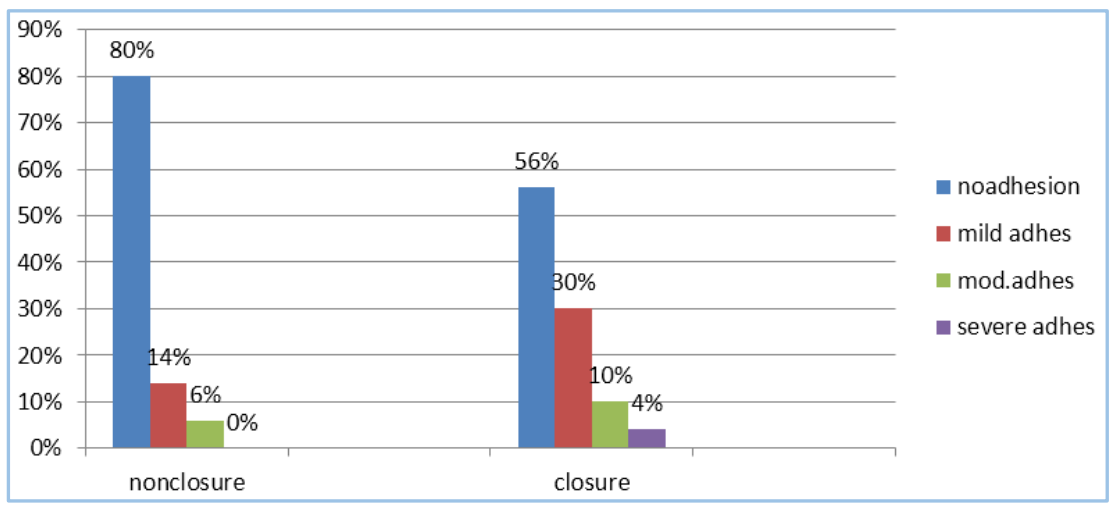

Bar Chart Showing Complications at $2^{\text {nd }}$ LSCS 


\section{DISCUSSION}

In this study there is shorter exposure to anaesthesia and lesser operation time in nonclosure group. This is consistent with Ghongdemath et al., Grundsell et al., Pietrantoni et al., Nagele et al., Saha et al.13,16-19 Less postoperative analgesic administration in open group due to less pain which was similar with Nagele et al., Hojberg et al., Rafique et al., Grundsell et al., Ghongdemath et al.13,14,17,18,20 Lower utilization of antibiotic due to lower febrile and infectious morbidity. This is also reflected by the other authors. ${ }^{9,13,16,17}$ Holtz and Elkins et al. ${ }^{2}$ mentioned that adhesion formation after peritoneal closure is mainly due to foreign body reaction to the suture material, interruption of vascular supply or ischaemia and inflammation. There is less tissue reaction in nonclosure cases due to absence of foreign body i.e. suture material which was supported by observers.8-12 On the other hand, peritoneal closure correlated with a significantly higher incidence of febrile morbidity and wound infection. This observations was correlated with.17,18 cystitis correlated with. ${ }^{21}$ endometritis with. ${ }^{18}$ increased postoperative pain with more narcotics use reflected in. ${ }^{14,1516,18}$ prolonged hospital stay was comparable with. ${ }^{16,17,18}$ and antibiotic use coincided with.12,18 Return of bowel function was correlated with. $14,15,17,21,22$

\section{CONCLUSION}

Operation time, Hospital stay, pain, adhesion formation, febrile and infectious morbidity were less in nonclosure patients during cesarean delivery. So, routine nonclosure of peritoneum at LSCS delivery is favorable.

\section{REFERENCES}

1. Duffy DM, diZerega GS. Is peritoneal closure necessary? Obstet Gynecol Surv 1994;49:817-22.

2. Elkins TE, Stovall TG, Warren J. A histological evaluation of peritoneal injury and repair: implication for adhesion formation, Obstet Gynecol 1987;70:225-8.

3. Hubbard TB, et al. The pathology of peritoneal repair. Its relation to the formation of adhesions. Ann Surg 1967;165:908-16.

4. Michael J, Zinmer Seymour I, Sechwartz, et al. Peritoneal healing. Maingot's abdominal operations 10th ed. International ed. Prentice Hall International Inc. 637-40.

5. Schwartz Shires Spencer Fisher Galloway. Physiology of the peritoneum. Principles of surgery 7 th ed. International ed 1999. McGraw-Hill. 1520-24.

6. Tulandi T, AI-Jaroudi D. Nonclosure of peritoneum: A reappraisal. Am J Obstet Gynecol 2003;189:609-12.

7. McDonald MN, et al. Adhesion formation and prevention after peritoneal injury and repair in the rabbit, J Reprod Med 1988;33:436-9.

8. Lower AM, Hawthorn RJ, Ellis H, et al. (2000). The impact of adhesions on hospital readmissions over ten years after 8849 open gynaecological operations: an assessment from the Surgical and Clinical Adhesions Research Study. Br J Obstet Gynaecol, 107, 855-862.
9. Pittaway D, Daniell J and Maxson W (1985). Ovarian surgery in an infertility patient as an indication for a short-interval second-look laparoscopy: a priliminary study. Fertil Steril, 44, 611.

10. Trimbos-Kemper T, Trimbos J and Van Hall E (1985). Adhesion formation after tubal surgery: results of the eighth-day laparoscopy in 188 patients. Fertil. Steril. 43, 395.

11. Victoria K, Anteby EY, Michael G, Simon S, Ofer L, Ofer G. Effect of closure versus nonclosure of peritoneum at cesarean section on adhesions: a prospective randomized study. Am J of Obstetrics and Gynecology. January 2012; 206:56e1-56e4.

12. Waraporn W, Sayan B, Manat K. Closure vs non-closure of the visceral and parietal peritoneum at cesarean delivery: 16 Year Study J Med Assoc Thai 2004;87(9):1007-11.

13. Ghongdemath JS, Banale SB. A randomized study comparing nonclosure and closure of visceral and parietal peritoneum during caesarean section: J of Obst \& Gyn of India, 61:48-52; 2011.

14. Højberg KE, Aagaard J, Laursen H, et al. Closure versus non-closure of peritoneum at cesarean section-evaluation of pain. A randomized study. Acta Obstet Gynecol Scand. 1998 Aug; 77(7):741-5.

15. Hull DB, Varner MW. A randomized study of closure of the peritoneum at cesarean delivery. Obstet Gynecol 1991;77:818-21.

16. Pietrantoni M, Parsons MJ, O’Brien WF. Peritoneal closure or non-closure at cesarean. Obstet Gynecol 1991;77:293-6.

17. Grundsell HS, Rizk DEE, Kuma RM. Randomized study of non-closure of peritoneum in lower segment cesarean section. Acta Obstet Gynecol Scand 1998;77:110-5.

18. Nagele F, Karas H, Spitzer D, Staudach A, Karasegh S, Beck A, et al. Closure or nonclosure of the visceral peritoneum at cesarean delivery. Am J Obstet Gynecol. 1996 Apr; 174(4):1366-70.

19. Saha SK, De KC, Bhattacharya PK, et al.: J of Obst \& Gyn of India, 51:34-36; 2001.

20. Rafique Z, Shibli KU, Russell IF. A randomised controlled trial of the closure or nonclosure of peritoneum at caesarean section: effect on post-operative pain. BJOG 2002;109:694-8.

21. Roset E, Boulvain M, Irion 0 . Nonclosure of the peritoneum during caesarean section: long-term followup of a randomized controlled trial. Eur J Obstet Gynecol Reprod Biol 2003;108:40-4.

22. Irion O, Luzuy F and Beguin F. Nonclosure of the visceral and parietal peritoneum at caesarean section: a randomised controlled trial. Br J Obstet Gynaecol, 1996;103:690-694. 